\title{
The problem of associated changes in protein thermostability during the process of speciation
}

\author{
BORIS P. UsHaKov \\ Laboratory of Comparative Cytology, Institute of Cytology, \\ Academy of Sciences of the USSR, Leningrad, USSR
}

\begin{abstract}
KURZFASSUNG: Das Problem der assoziierten Veränderungen in der Proteinthermostabilität während des Prozesses der Speziation. Neue Versuchsergebnisse über die Thermostabilität der Eiweiße nahe verwandter Tierarten (Würmer, Mollusken, Crustaceen, Fische, Amphibien, Reptilien und in gewissem Umfang auch Säugetiere) werden diskutiert und vergleichend analysiert. Die im Laboratorium für Vergleichende Cytology durchgeführten Experimente ergaben, daß das Ausmaß der Unterschiede in der Thermostabilität aller untersuchten Eiweiße nahe verwandter Tierarten große Ahnlichkeiten aufweist. Die interspezifischen Unterschiede werden auf Differenzen in der Hitzeresistenz der Proteine selber zurückgeführt. Da interspezifische Unterschiede in der Thermostabilität sogar in recht nahe verwandten Arten festgestellt wurden, wird gefolgert, daß die assoziierten Veränderungen in der Proteinthermostabilität im Verlauf der Speziation entstanden sind. Die an verschiedenen intraspezifischen Gruppen mehrerer Tierarten erhaltenen Ergebnisse deuten ferner darauf hin, daß diese Veränderungen in einer bestimmten Reihenfolge auf dem Wege der natürlichen Selektion zustande gekommen sind und schließlich den überwiegenden Teil der Eiweiße des Organismus betreffen. Als Ergebnis entstehen Arten, welche sich hinsichtlich ihrer Proteinthermostabilität unterscheiden; die Unterschiede nehmen zu mit der Differenz zwischen Reproduktions- und Umwelttemperatur. Die biologische Bedeutung der interspezifischen Unterschiede in der Proteinthermostabilität wird diskutiert.
\end{abstract}

\section{INTRODUCTION}

A comparative study on physiological and biochemical characteristics of systematically closely related species of animals, that is animals of the same genus, is to be made in order to analyse changes which arise during speciation. Such an approach is employed in the Laboratory of Comparative Cytology (Institute of Cytology, Academy of Sciences of the USSR) for the investigation of heat resistance of tissues, cells, and tissue proteins (UsHakov 1964a, b). The information obtained indicates that closely related animal species differ in their cell thermostability. The more pronounced a variation between reproductive and environmental temperatures, the greater is the difference in cellular thermostability of the species compared. Differences in heat resistance have been discovered in all cells and tissues investigated so far.

Whereas variations in cell thermostability were observed in more than 250 species, differences in protein heat resistance have been thoroughly investigated only in 
two close species of frogs, namely Rana temporaria and Rana ridibunda (Table 1). The present paper deals with new experimental data concerning variations in thermostability of tissue proteins within a wider range of systematically close species. Two main problems will be discussed: first, to what extent interspecific differences in the thermostability are characteristic to all proteins of the organism; second, to what extent these differences can be revealed in studies on animals from different classes and types. In conclusion, two more questions will be considered: first, correlation between the heat resistance of various proteins in systematically remote species, and, second, the origin of interspecific variations in protein thermostability during speciation.

The experimental material dealt with in the present communication was obtained by the workers of our laboratory, M. A. Giushankova, A. A. Kusakina, E. E. Makhlin, K. I. Pravdina, E. D. Skholl, and A. N. Vinogradova. Up to the present time, tissue proteins from 54 animal species (largely poikilotherms) have been studied to various extents. The maximal number of protein preparations studied for one pair of closely related species amounts to 11 .

\section{UNIVERSALITY OF DIFFERENCES IN THE THERMOSTABILITY OF HOMOLOGOUS PROTEINS IN CLOSELY RELATED SPECIES}

\section{Interspecific differences in thermostability of proteins with various functions}

The experimental evidence presented in Table 1 shows differences in the heat resistance of some proteins in two frog species, Rana temporaria and $R$. ridibunda. As has been mentioned, this pair of species was studied most completely and therefore is best suited for demonstration of the universality of differences in protein thermostability in closely related species.

Most of the material had already been reported elsewhere (MAKHLIN 1963, Ushakov 1964b, 1965). New data are presented in the last three lines of Table 1. These data obtained on three more enzymes support the idea of interspecific differences in protein thermostability. They are also in close agreement with the evidence previously obtained for the other proteins as well as for tissues and cells of the two species compared.

Newest data seem to be important not only because they confirm the general idea, but also because they were obtained in experiments with adenylatkinase (myokinase) and alkaline phosphatase. The experiments with adenylatkinase are of prime importance since this enzyme is one of the most thermostable proteins and during the process of isolation is exposed to extremely high temperature $\left(90^{\circ} \mathrm{C}\right)$. The difference in heat resistance of such stable protein correlates with that in environmental temperatures of the species. This might seem to be a paradoxical fact which could not be predicted provided one is not aware of the results obtained on other proteins.

Experiments with alkaline phosphatase are also noteworthy because LrcHT (1964b) was not able to demonstrate any difference in the thermostability of this enzyme in several distant species of lizards, though he did find it in the case of 


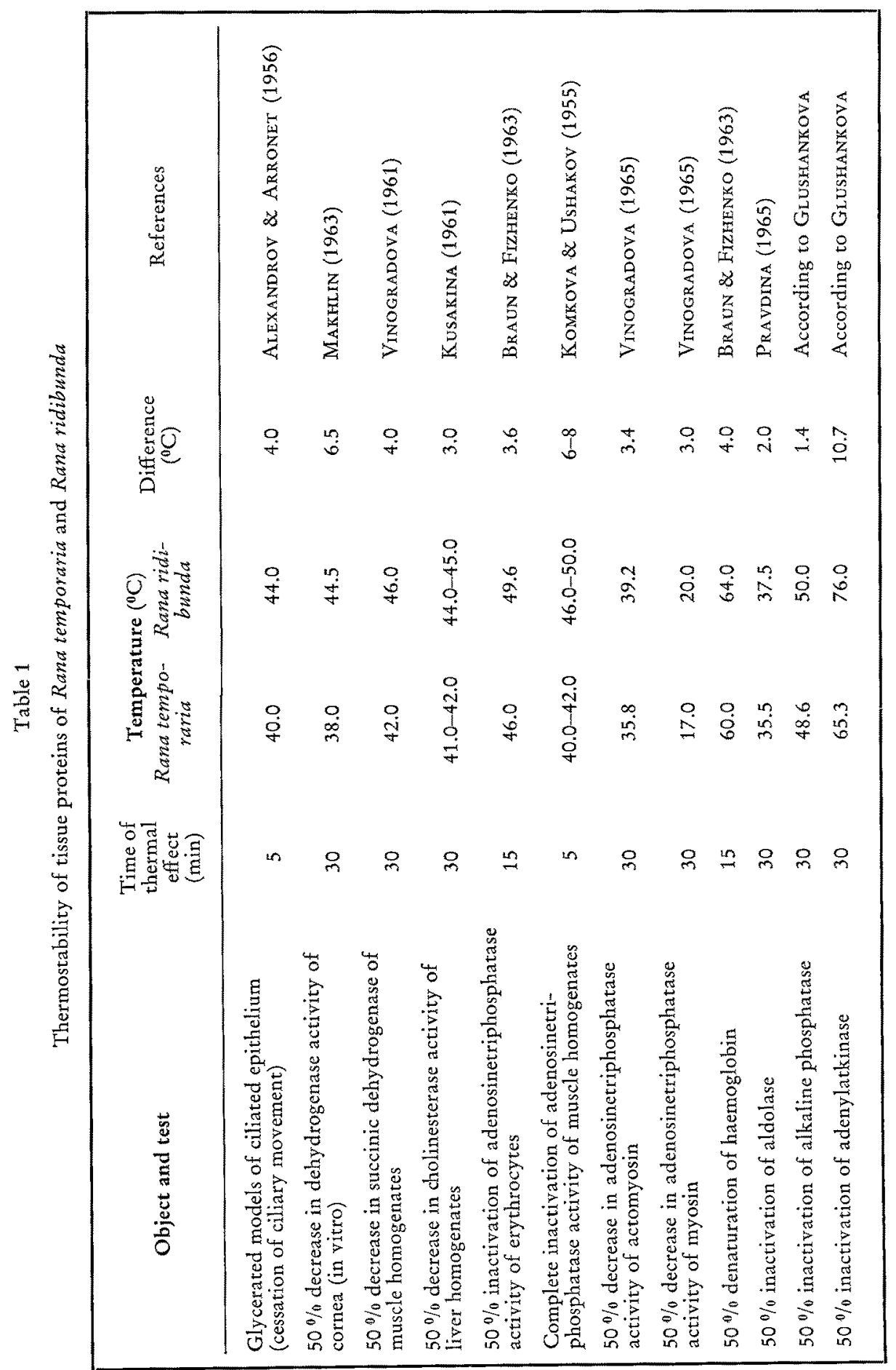


Protein thermostability during speciation

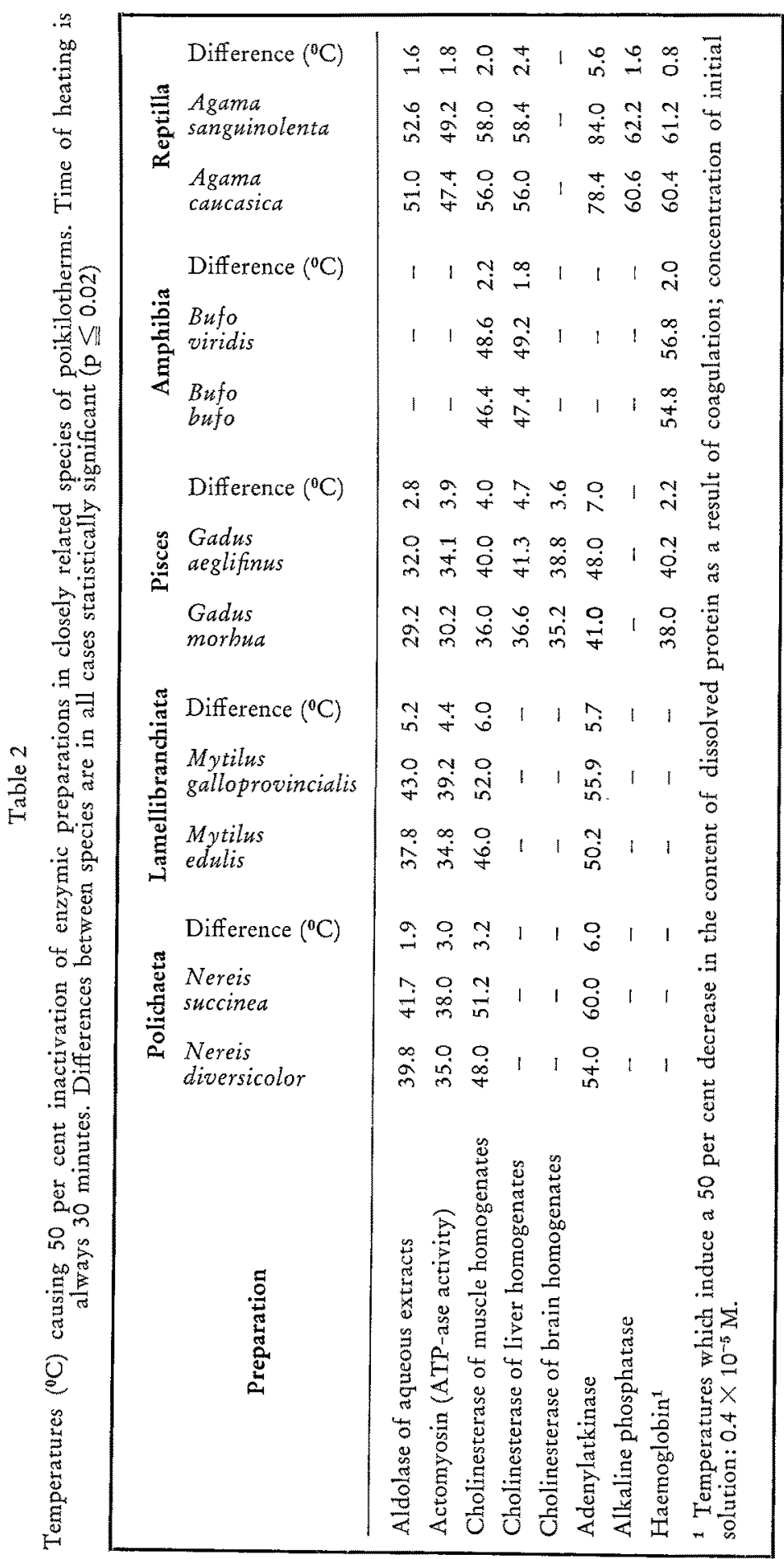


actomyosin. Interspecific variations in the heat resistance of alkaline phosphatase were detected in our laboratory for two species of crayfish (Astacus astacus and A. leptodactylus) and lizards (Agama caucasica and A. sanguinolenta).

The negative results of LICHT's experiments are presumably due to (1) a lesser range of interspecific differences in the thermostability of alkaline phosphatase as compared with other proteins, and (2) to the fact that he studied the inactivating effect of moderate temperatures while this difference is more clearly shown following a more intensive thermal stress.

The choice of proteins depended on methodical conveniences. For the experiments we used proteins varying in their function, localization in a cell, solubility and heat resistance. Nevertheless, not a single pair of proteins with identical thermostability has been found. From this fact it may be concluded that interspecific differences in protein thermostability are universal since they are characteristic for the bulk of homologous proteins in closely related species.

\section{Interspecific differences in thermostability of proteins from different types of animals}

In order to answer the question whether or not a correlation found for the two frog species is also applicable to other groups of animals, experiments with closely related species from different types and classes were made. A portion of the material obtained in our laboratory is given in Table 2. We compared the heat resistance of proteins from 5 pairs of species belonging to worms, mollusks, fishes, amphibians and reptiles. Interspecific differences in the thermostability of proteins were revealed in all cases. For each pair they are correlated both with the environmental temperatures and cell thermostability. It should be noted that variation in the thermostability of cells and proteins appear to be of the same order; adenylatkinase and alkaline phosphatase are the exceptions to this general rule. The range of variation in the thermostability of adenylatkinase is higher in comparison to other proteins. For alkaline phosphatase this range was smaller than for other proteins studied. A similar phenomenon was discovered earlier when we compared protein heat resistance in frog species (Table 1).

Similar differences in thermostability were found in actomyosin of two species of rays, Raja radiata and $R$. clavata (VINOGRADOva 1963a) and in hemoglobins of four macaca species (KUSAKINA \& SKHOLL 1963). Variations in the heat resistance of actomyosin from gills and muscles were also found in two species of freshwater molluscs, Unio crassus and $U$. tumidus. In addition, these differences were discovered for some proteins of river crayfish, Astacus astacus and A. leptodactylus. It should be pointed out that these studies, made within a wide phylogenetic range of species, did not reveal a single exception to the general rule, that is, not one pair of closely related animal species has been discovered without significant differences in the heat resistance of its proteins.

Similar results were obtained by comparison of protein heat resistance in systematically distant species. It has been found that protein thermostability is correlated with microclimatic environmental conditions of species. This conclusion was derived from experiments with actomyosin (Vinogradova 1963a, b, c), transaminase of 
asparatic and glutamic acids (READ 1963, 1964) of marine invertebrates (crabs and molluscs), muscle cholinesterase of Baikalian fish (KuSAKINA 1962), actomyosin and hemoglobin of reptiles (Vinogradova 1963b, Licht 1964a, Kusakina 1965)1.

The evidence discussed indicates that variation in the thermostability of proteins in closely related animal species is a universal phenomenon, which can be demonstrated by comparative investigations of animals from different classes and types.

\section{THE EFFECT OF PURIFICATION OF TISSUE PROTEINS ON INTERSPECIFIC DIFFERENCES IN THEIR THERMOSTABILITY}

Various concomitants may influence the thermostability level of proteins. Therefore the question arises whether variations in thermostability may serve as an index of differences between proteins or whether they are due to protein contamination (Kusakina 1963, Belemradek 1964, Ushakov 1964a, 1965). When discussing this question, one should consider the fact that interspecific variations in thermostability similar in direction and usually also in range of fluctuation have been discovered both in tissue homogenates and in proteins purified to a various extent. This means that differences in thermostability are not affected by the presence of substances which may contaminate proteins.

Another essential fact is that the range of interspecific variations in heat resistance does not undergo any significant changes during purification. This statement is illustrated by Figure 1, representing a comparison of actomyosin and myosin thermostability of the frogs Rana temporaria and $R$. ridibunda (VInOgRadova 1965). The heat resistance of purified myosin is considerably lower than that of actomyosin. However the differences in thermostability of purified enzymes remain practically the same between the species compared. This observation indicates that variation in contents of a protein in complex influences thermoresistance but does not alter the amplitude of interspecific variations.

Recently we made experiments to compare the heat resistance of proteins of various degrees of purification. In addition to myosin, we purified aldolase and adenylatkinase. The thermostability of these enzymes did not significantly change upon their purification. Interspecific differences in thermostability were also observed for the crystalline form of arginine phosphokinase from two species of crayfish of the genus Astacus.

All these data indicate that interspecific differences in the thermostability of proteins must be related to the proteins themselves but are not the result of their contamination. Investigations of GUSTAvson (1956) and FrSHAM \& LEVI (1964), which establish a relationship between the heat resistance of collagen in various fish species and the amount of its molecular proline and oxyproline, support this conclusion. Not only do these papers confirm the dependence of protein heat resistance on amino acid

1 Wicson et al. (1964) studied the heat resistance of lactate dehydrogenase in a number of taxonomically distant species. However they did not ched the relation between enzymic thermostability and environmental conditions of species; a comparison of our data with theirs is therefore difficult. 
composition of the former, but - as in our own experiments - establish a direct relation of collagen thermostability to the environmental temperature of fish species.

According to BELEHRADEK (1964), a difference in protein thermostability is directly related not to the structure of the protein itself but to the protective effect of

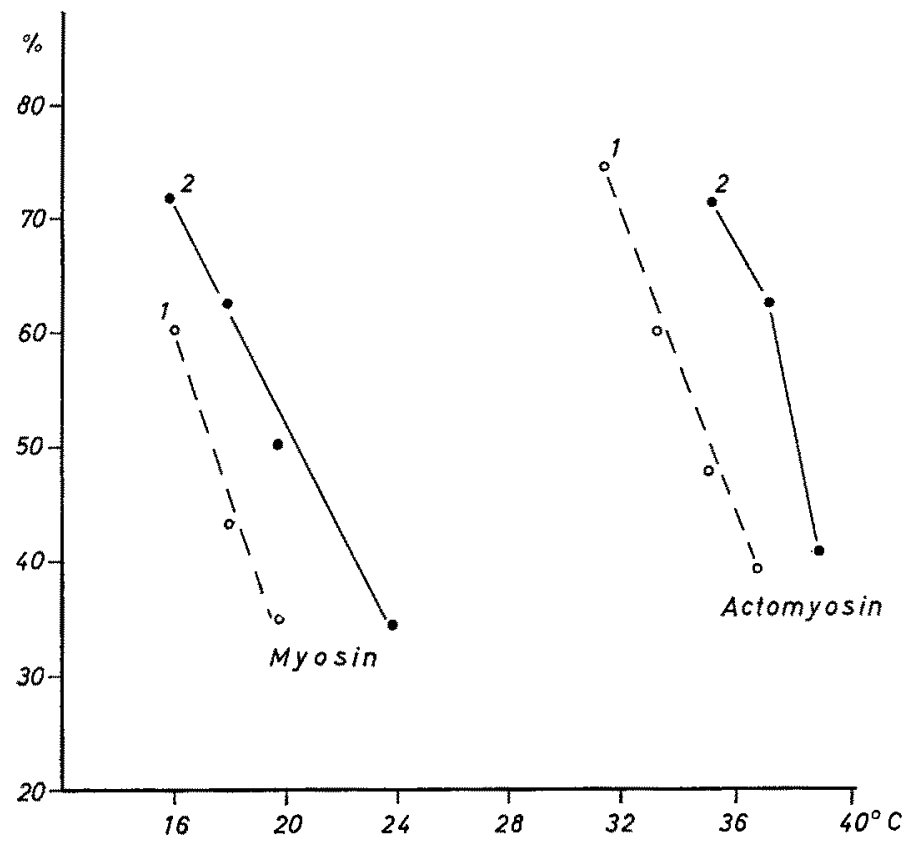

Fig. 1: Myosin and actomyosin thermostability in the frogs Rana temporaria and Rana ridibunda. Abscissa: temperature of preliminary heating for 30 minutes (in ${ }^{\circ} \mathrm{C}$ ); ordinate: residual ATPase activity (in per cent of initial level), 1: Rana temporaria, 2: Rana ridibunda. (After Vinogradova 1965)

lipids. As discussed in detail in earlier publications (Ushakov 1964a, 1965), the viewpoint which associates cell thermostability with the melting temperature of lipids (especially with their iodine numbers) is not supported by experimental evidence. It appears that lipids, similar to other non-protein substances, may influence the thermostability of tissue proteins. However, no data are available which demonstrate that the range of interspecific variations in protein thermostability depends upon differences in lipids. Experiments of Glushankova (1963) do not confirm BeleHradeK's point of view. GluSHanKova showed differences in actomyosin thermoresistance of large and small forms of Trachurus mediterraneus correlated with the environmental temperatures of the fish, while lipids from actmyosin preparations possessed the same iodine number. Consequently, a difference in actomyosin thermostability cannot be due to variation in the melting temperature of its lipids.

On the basis of the facts mentioned above, it may be concluded that differences in protein thermostability are directly related to those in protein structure. Such a conclusion indicates that speciation results in profound re-arrangements within the organisms, accompanied by associated changes in the main bulk of their proteins. 
It is of interest to compare our results with recent investigations which show a similarity in the sequence of amino-acids in the primary structure of proteins with different functions (VEGotsky \& Fox 1962, WiLson et al. 1964). Although these data are few in number and the experiments were made with systematically distant species, they might be of great value since they allow the suggestion that correlation in changes of the heat resistance of various proteins during speciation presumably provides a physico-chemical index revealing a similarity of changes in the primary structure of functionally different proteins upon divergence of organisms.

\section{CORRELATION BETWEEN THE THERMOSTABILITY OF VARIOUS PROTEINS}

On the previous pages we compared the heat resistance of proteins in systematically closely related species. In order to obtain a more complete picture of associated changes in protein thermostability during evolution, it is desirable to compare correlations in thermostability levels of various proteins from different animals, including taxonomically distant species.

Axtomyosin thermostability was most completely studied. Consequently, correlations between the thermostability of actomyosin on one hand, and aldolase, cholinesterase and adenylatkinase on the other have been investigated (Fig. 2). The correlation coefficients found are: for aldolase, 0.89 (12 species); for cholinesterase, 0.74 ( 13 spiecies); and for adenylatkinase, 0.89 (11 species).

Despite the positive correlation coefficient in all the cases studied, the slope of the resulting lines is different for various proteins (Fig. 2). Since the thermostability of aldolase in different animal species is usually similar to that of actomyosin, the relationship between these proteins is indicated by a straight line approximating a bisector. The heat resistance of cholinesterase as a rule is several degrees higher in comparison to actomyosin. However, an increase in thermostability from one species to another is accompanied by an equal increase in heat resistance of both enzymes. This relation is different in the case of adenylatkinase, its increase in thermostability outstripping that of actomyosin. Consequently, interspecific differences in adenylatkinase heat resistance appear to be more significant when compared to variations in the thermostability of other enzymes. Further experimental data have shown that the relationship between the thermostabilities of proteins varying in function in poikilothermal animals may be expressed by the system of straight line equations:

$T_{0}+A_{1} T_{1 n}+B_{1}+A_{2} T_{2}+B_{2}=A_{3} T_{3}+B_{3}=A_{n} T_{n}+B_{n}$, where $T_{0}, T_{1}$, $T_{3} \ldots T_{n}$ represent the temperature causing a $50 \%$ inactivation of enzymes and $A_{1}, A_{2}, A_{3} \ldots A_{n}$ and $B_{1}, B_{2} B_{3} \ldots B_{n}$ the constants of the straight line equations. This material was reported at the symposium "Molecular Mechanisms of Temperature Adaptation" held in Berkeley (U.S.A.) in December 1965.

Hence, associated changes in protein heat resistance do occur during evolution, although the degree of such changes may be different in various proteins. The thermostability of proteins is correlated with the environmental conditions not only in closely related species but also in systematically distant ones. A comparison of this 
fact with the evidence discussed above allows the conclusion that, in the process of phylogenetic adaptation of organisms to new thermal conditions, the thermostability of various proteins changes unequally: some proteins undergo more significant changes than others.
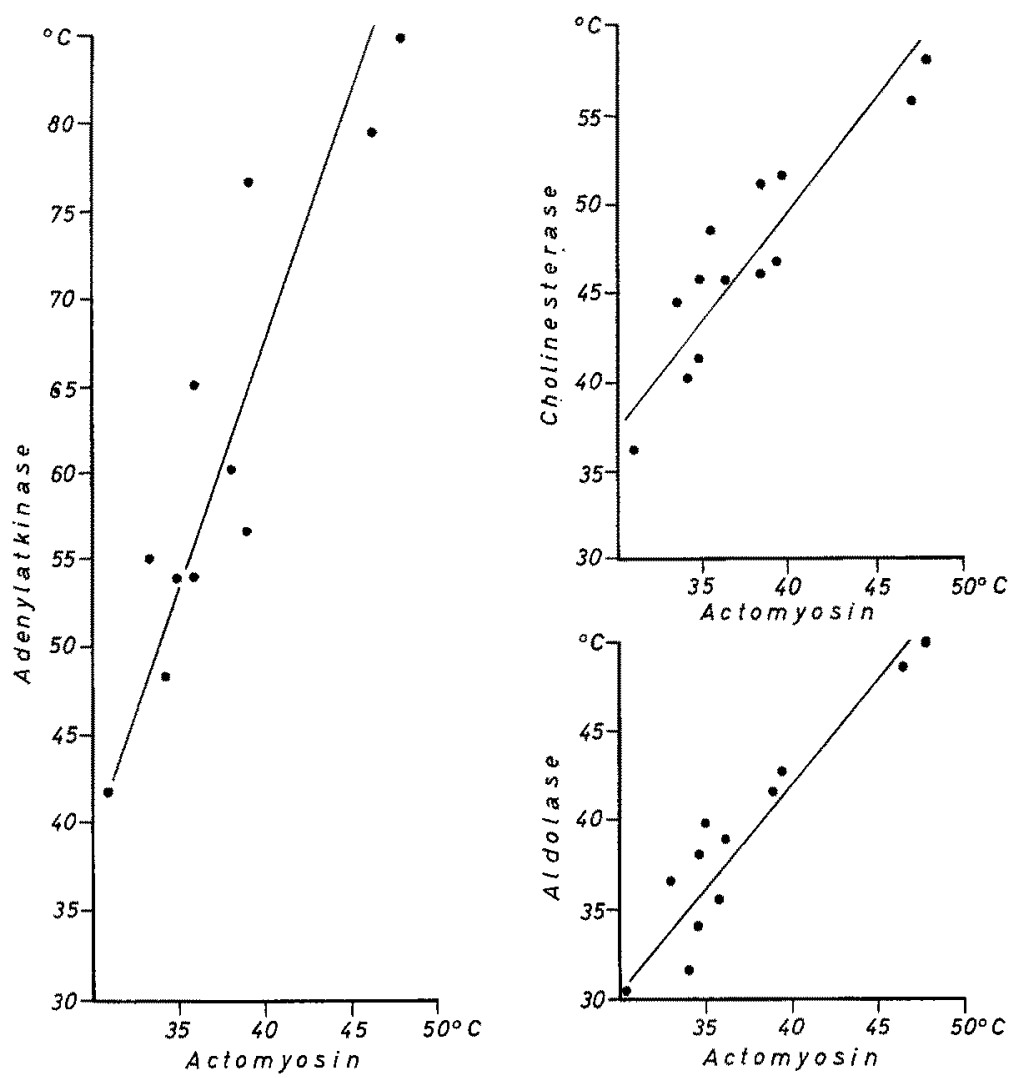

Fig. 2: Correlations between the thermostability of various proteins within one and the same species. Axes represent temperatures of $50 \%$ inactivation. Time of heating is 30 minutes. Each point indicates one species

\section{ORIGIN OF ASSOCIATED CHANGES IN PROTEIN THERMOSTABILITY DURING SPECIATION}

In order to explain the origin of associated changes in protein thermostability during the process of speciation an analysis of various intraspecific groups of polytypical species differing in heat resistance of their cells and proteins should be made. Intraspecific divergence with regard to thermostability has previously been studied in 6 species (Altukhov 1962, Ushakov, Vinogradova \& Kusakina 1962, Ushakov 1963a, Braun \& Fizhenko 1963, Vinogradova \& Kusakina 1963, Glushankova 1963, Oganesyan \& Petrosyan 1965). These experiments revealed species exhibiting 
associated changes in protein thermostability within various populations and races, similar to those in closely related species. In one such species, the Baikalian Thymalus arcticus, thermostability of cholinesterase and ATPase varied in white and black races (Table 3). Differences in enzymic thermostability were found to be of the same magnitude as variations in heat resistance of muscle tissue. In this case the divergence seems to have progressed so far that a question arises whether investigators are dealing with twin species or different races of the same species; the latter view is supported by reproductive isolation of these races.

Table 3

Thermostability of myocard and some protein preparation of Baikalian Thymalus arcticus (time of heating: 30 minutes according to UsHAKOV, VINOGRAdOVA \& KUSAKINA 1962)

\begin{tabular}{|c|c|c|c|}
\hline \multirow[b]{2}{*}{ Object and test } & \multicolumn{2}{|c|}{ Temperature $\left({ }^{\circ} \mathrm{C}\right)$} & \multirow[b]{2}{*}{$\begin{array}{c}\text { Difference } \\
\left({ }^{\circ} \mathrm{C}\right)\end{array}$} \\
\hline & $\begin{array}{l}\text { White } \\
\text { race }\end{array}$ & $\begin{array}{l}\text { Black } \\
\text { race }\end{array}$ & \\
\hline \multirow{3}{*}{$\begin{array}{l}\text { Myocard (loss of excitability) } \\
50 \% \text { decrease in dholinesterase activity of } \\
\text { muscle homogenates } \\
50 \% \text { decrease in adenosinetriphosphatase } \\
\text { activity of muscle homogenates }\end{array}$} & 28.0 & 30.0 & +2.0 \\
\hline & 37.4 & 39.2 & +1.8 \\
\hline & 33.8 & 36.0 & +2.2 \\
\hline
\end{tabular}

Other investigations revealed cases of less advanced divergence. Thus Posolsk and North-Baikalian races of Coregonus autumnalis differ in thermostability of muscle tissue and cholinesterase, but no significant difference was discovered in ATPase heat resistance (Table 4). Associated changes in the thermostability of some proteins and muscle cells were found between populations of the frog, Rana ridibunda, from the European part of the USSR and Central Asia (Table 5). However, no differences were observed in these frog populations between heat resistance of alkaline phosphatase, spermatozoans and ciliated epithelium. Differences in haemoglobin thermostability are opposite in direction relative to other pairs of homologous proteins.

Although evidence is scanty, it suggests that associated changes in heat resistance of various proteins occur in some succession but not simultaneously. Experiments with

Table 4

Thermostability of myocard and some protein preparations of Baikalian Coregonus antumnalis (time of heating: 30 minutes according to USHAKOV, VINOGRADOVA \& KUSAKINA 1962)

\begin{tabular}{|c|c|c|c|}
\hline Object and test & $\begin{array}{c}\text { Temr } \\
\text { Posolsk }\end{array}$ & $\begin{array}{l}\text { e }\left({ }^{\circ} \mathrm{C}\right) \\
\text { North } \\
\text { Baikalian }\end{array}$ & $\begin{array}{l}\text { Difference } \\
\left({ }^{\circ} \mathrm{C}\right)\end{array}$ \\
\hline $\begin{array}{l}\text { Myocard (loss of excitability) } \\
50 \% \text { decrease in cholinesterase activity of } \\
\text { muscle homogenates } \\
50 \% \text { decrease in adenosinetriphosphatase } \\
\text { activity of muscle homogenates }\end{array}$ & $\begin{array}{l}30.0 \\
39.5 \\
35.5\end{array}$ & $\begin{array}{l}28.2 \\
40.0 \\
35.5\end{array}$ & $\begin{array}{l}-1.8 \\
+0.5^{1} \\
0\end{array}$ \\
\hline The difference is statistically significant. & & & \\
\hline
\end{tabular}


Table 5

Thermostability of cells and some protein preparations of Rana ridibunda belonging to Asiatic and European intraspecific groups

\begin{tabular}{|c|c|c|c|c|c|}
\hline Object and test & $\begin{array}{l}\text { Time of } \\
\text { thermal } \\
\text { effect } \\
\text { (min) }\end{array}$ & $\begin{array}{l}\text { Tempera } \\
\text { Asiatic Eu }\end{array}$ & $\begin{array}{l}\text { ature } \\
\text { uropean }\end{array}$ & $\begin{array}{l}\text { Differ- } \\
\text { ence } \\
\left({ }^{\circ} \mathrm{C}\right)\end{array}$ & References \\
\hline Spermatozoa (loss of movements) & 30 & 41.4 & 41.4 & 0 & SVINKIN (1959) \\
\hline $\begin{array}{l}\text { Ciliated epithelium (cessation of } \\
\text { ciliary movement) }\end{array}$ & 5 & $44.4-44.8$ & 44.4 & 0 & $\begin{array}{l}\text { ALEXANDROV (1952) } \\
\text { ARRONET (1964) }\end{array}$ \\
\hline Muscles (loss of excitability) & 30 & 39.0 & 40.2 & +1.2 & UsHaKov $(1963 a)$ \\
\hline $\begin{array}{l}50 \% \text { dicrease in cholinesterase } \\
\text { activity of muscle homogenates }\end{array}$ & 30 & 46.0 & 46.9 & +0.9 & $\begin{array}{l}\text { VinOGRADOVA } 8 x \\
\text { KUSAKINA }(1963)\end{array}$ \\
\hline $\begin{array}{l}50 \% \text { decrease in cholinesterase } \\
\text { activity of liver homogenates }\end{array}$ & 30 & 47.2 & 47.8 & +0.6 & $\begin{array}{l}\text { Vinogradova \& } \\
\text { KuSAKINA (1963) }\end{array}$ \\
\hline $\begin{array}{l}50 \% \text { decrease in adenosinetriphos- } \\
\text { phatase activity of actomyosin }\end{array}$ & 30 & 38.4 & 39.9 & +0.8 & $\begin{array}{l}\text { VINOGRADOVA \& } \\
\text { KUSAKINA (1963) }\end{array}$ \\
\hline $50 \%$ coagulation of haemoglobin & 15 & 65.0 & 64.0 & -1.0 & $\begin{array}{l}\text { BRAUN \& } \\
\text { FIzHENKO (1963) }\end{array}$ \\
\hline $\begin{array}{l}50 \% \text { decrease in aldolase activity } \\
\text { of muscle homogenates }\end{array}$ & 30 & 34.0 & 37.5 & +3.5 & $\begin{array}{l}\text { According to } \\
\text { Pravdina }\end{array}$ \\
\hline $\begin{array}{l}50 \% \text { decrease in alkaline } \\
\text { phosphatase }\end{array}$ & 30 & 50.4 & 50.0 & $-0.4^{t}$ & $\begin{array}{l}\text { According to } \\
\text { GLUSHANKOVA }\end{array}$ \\
\hline $50 \%$ decrease in adenylatkinase & 30 & 70.0 & 76.0 & +6.0 & $\begin{array}{l}\text { According to } \\
\text { GLUSHANKova }\end{array}$ \\
\hline
\end{tabular}

two frog populations indicate that non-associated variations may appear at certain stages of speciation.

\section{BIOLOGICAL SIGNIFICANCE OF ASSOCIATED CHANGES IN PROTEIN THERMOSTABILITYY DURING SPECIATIION}

The question of biological significance of associated changes of proteins during speciation is essential, but its experimental investigation is somewhat embarassing. In this paper only general suggestions will be made concerning possible approaches to this complicated problem.

The following difficulties arise in studies concerned with this question. The problem of biological significance of interspecific differences in thermostability of proteins cannot be substituted by that of cells. Firstly, cellular heat resistance has an adaptive significance for a species only at early stages of ontogenesis when the organism passes through oligocellular stages of development (gametes, zygotes, early stages of cleavage). During differentiation the main bulk of cells in the organism acquires higher thermostability in comparison to the organism as whole. Thus thermostability of cells loses its adaptive significance for the animal as a whole with respect to detrimental 
effects of temperature (UsHakov 1964a). Secondly, for cellular thermostability not all the proteins are equally important: thermolabile proteins which limit heat resistance of a cell as a whole play the most significant role (UsHakov 1965). Hence differences in thermostability of such stable proteins as, for example, adenylatkinase, cholinesterase, haemoglobin and others cannot be directly related to differences in cellular thermostability, and therefore they require a special explanation.

If associated changes in protein thermostability during speciation result from adaptation of animals to the injurious effects of temperature, they must primarily occur in proteins which limit the thermostability of gametes and embryonic cells at early cleavage stages in relation to changes in reproductive temperature. In this case changes in thermostability of highly resistant proteins may be regarded as secondary phenomenon.

However, it is possible to give another explanation to the evidence obtained. It may be suggested that associated changes of proteins occuring during speciation appear not as a result of adaptation of animals to the detrimental effects of temperature ("resistance adaptation", according to PRECHT's terminology) but are due to phylogenetic adaptation of organisms within the range of normal temperatures ("capacity adaptation"). In other words, it may be suggested that the thermostability of enzymes is correlated with their activity at normal temperatures ${ }^{2}$.

If this supposition is correct, it means that associated thermostability levels of both thermostable and thermolabile proteins should be regarded as physico-chemical indexes of phylogenetic temperature adaptation devoid of its own significance.

The question whether associated changes of proteins are the consequence of adaptation of the organism to the detrimental effects of extreme temperatures or a consequence of changes in their functioning within the range of normal temperatures, is complicated by methodical difficulties in isolating chemically pure proteins in the majority of poikilotherms. Because changes in thermostability do not simultaneously occur upon intraspecific divergencies of proteins with different functions, an historical method of study on this question seems to be most suitable. If associated changes of proteins result from adaptation of animals to detrimental temperature effects at the early stages of divergences one should expect changes in thermostability of proteins which limit the heat resistance of eggs and embryos at early stages of development.

There are some indirect indications that changes of proteins are the consequence of adaptation of animals to the injurious temperature effects (UsHaKov 1964b). However these viewpoints do not exclude each other since in evolution both possibilities may be realized at various stages of orthogenesis.

The material discussed indicates that associated changes of proteins do occur during the process of speciation. It may be concluded that natural selection involves successive changes which finally lead to alterations in the main bulk of proteins of the

2 Changes in activity of enzymes which provide constancy of metabolism during acclimation of animals were reported in several investigations (PRECHT, CHRISTOPHERSEN \& HENSEL 1955, PRECHT 1958, USHAKOV \& KuSAKINA 1960, Prosser 1964, and others). Unfortunately these works concern phenotypic reactions of the organism and consequently cannot be referred to interspecific differences which are of genotypic nature. Moreover, they comprise no experimental data revealing a relation of the function of enzymes to their heat resistance, since an analysis of this phenomenon has not been carried out at the molecular level. 
organism. Consequently, species appear which differ in protein thermostability; the differences involved increase with the differences in reproductive and environmental temperatures.

The material discussed further supports the idea that a species represents an entity of populations with general physico-chemical properties of protein structure (UsHAKov 1964a).

\section{SUMMARY}

1. New data are discussed comparing the thermostability of proteins in closely related species of worms, mollusks, crustaceans, fishes, amphibians, reptiles and, to some extent, mammals by the Laboratory of Comparative Cytology.

2. The differences in thermostability of all proteins studied in different pairs of species were similar. These interspecific variations were found to be due to differences in heat resistance of the proteins themselves.

3. Since interspecific differences in thermostability were discovered even in closely related species, this evidence permits the conclusion that associated changes in protein thermostability occur during speciation.

4. The analysis of protein heat resistance performed on various intraspecific groups of several animal species suggests that this alteration is accomplished by natural selection in a certain succession and finally involves the main bulk of the proteins of the organism. As a result species are formed which increasingly differ in protein thermostability with increasing variations in their reproductive and environmental temperatures.

5. The biological significance of interspecific differences in protein thermostability and a methodical approach to the solution of this problem are discussed.

\section{LITERATURE CITED}

Alexandrov, V. J., 1952. The relation between thermostability of protoplasm and environmental temperature conditions. Dokl. Akad. Nauk SSSR 83, 149-152.

- 1964. A study of the changes in resistance of plant cells to the action of various agents in the light of cytoecological consideration. In: The cell and environmental temperature. Ed. by A. S. Troshin. USSR Acad. Sci., Moscow; Pergamon pr., Oxford, U.K., 98-104.

- \& Arronet, N. I., 1956. Adenosinetriphosphate cause the movement of cilia in ciliate epithelium killed by glycerine extraction (a "cellular model"). Dokl. Akad. Nauk SSSR $110,457-460$.

Altukhov, Ju. P., 1962. A study of the thermostability of isolated muscles of "large" and "small" Trachurus mediterraneus from the Bladk Sea. Trudy Karadah. nauch. Sta. 18, 3-16, Lrov.

ARronet, N. I., 1964. The site of application of an injurious thermal action in the cell. Dokl. Akad. Nauk SSSR 157, 437-439.

BeteHRADek, J, 1964. Intermolecular aspects of the structural stability of protoplasma at the temperature extremes. In: The cell and environmental temperature. Ed. by A. S. Troshin. USSR Acad. Sci., Moscow; Pergamon pr., Oxford, U.K. 289-296.

Braun, A. D., Nesvetajeva, N. M. \& Frzhenko, N. V., 1959. On actomyosine resistance of grass and lake frogs to denaturating action of temperature and alcohol. Tsitologiya 1 , 86-93. 
- \& Fizhenko, N. V., 1963. On the thermostability of erythrocytes and their proteins ATPase and haemoglobin in two species of the frog. Tsitologiya 5, 249-253.

-, Nesvetajeva, N. M. \& Fizhenko, N. V., 1964. The relation between resistance of cells and tissues to damage and denaturation capacity of proteins. In: The cell and environmental temperature. Ed. by A. S. Troshin. USSR Acad. Sci., Moscow; Pergamon pr., Oxford, U.K., 228-233.

Glushankova, M A., 1963. Examination of the thermostability of actomyosin preparations and the iodine number of isolated lipids in Trachurus mediterraneus from the Black Sea. Tsitologiya 5, 244-246.

Gustavson, K. H., 1956. The chemistry and reactivity of collagen. Acad. Pr., New York, $342 \mathrm{pp}$.

Komkova, A. I. \& Ushakov, B. P., 1955. Temperature inactivation of muscle ATP ase in grass and lake frogs. Dokl. Akad. Nauk SSSR 102, 1185-1188.

Kusakina, A. A,, 1961. Rate of decrease in cholinesterase activity in liver homogenates of Rana temporaria and Rana ridibunda as dependent on temperature. Dokl. Akad. Nauk SSSR 139, 1258-1261.

- 1963. Relation of muscle and cholinesterase thermostability in certain fishes to specific environmental temperature conditions. Fedn Proc. Fedn Am. Socs exp. Biol. 22, 123-126 (Transl. Suppl.).

- 1963. Species differences in heat resistance of protoplasmic proteins. In: Problems of cy toecology of animals. USSR Acad. Sci., Moscow, 169-188 (Summary in English).

- 1965. Haemoglobin thermostability of five species of lizards from Kara-Kum Desert. In: Heat resistance of cells of animals. Moscow, 213-216.

- \& Skroll, E. D., 1963. Thermostability of the erythrocytes and haemoglobin derivatives of four Macaca species. Tsitologiya 5, 253-257.

Licht, P., 1964a. The temperature dependence of myosin-adenosine triphosphatase and alkaline phosphatase in lizards. Comp. Biochem. Physiol. 12, 331-340.

- 1964b. A comparative study of the thermal dependence of contractivity in saurian skeletal muscle. Comp. Biochem. Physiol. 13, 27-34.

Makhlin, E. E., 1963. Heat resistance of protein complexes of corneas of Rana temporaria L. and Rana ridibunda PALL. In: Problems of cytoecology of animals. USSR Acad. Sci., Moscow, 199-208 (Summary in English).

Hovanessian, S. S. \& Petrossian, V. P., 1964. The study of actomyosin thermostability of sceletal muscles of sevan trout. In: The cell and environmental temperature. Ed. by A. S. Troshin. USSR Acad. Sci., Moscow, Pergamon pr., Oxford, U.K., 233-235.

Pravdina, K. I., 1965. The thermostability of aldolase in taxonomically related species of amphibians. In: Heat resistance of cells of animals. Moscow, 193-199.

PRECHT, H., 1958. Concepts of the temperature adaptation of unchanging reaction system of coldblooded animals. In: Physiological adaptation. A symposium ... Ed. by C. L. Pros ser. Am. Physiol. Soc., Washington, D.C., 52-78.

-, Christophersen, J. \& Henser, H., 1955. Temperatur und Leben. Springer, Berlin, 514 pp

Prosser, C. L., 1964. Metabolic and nervous acclimation of fish to cold. In: The cell and environmental temperature. Ed. by A. S. Troshin. USSR Acad. Sci., Moscow; Pergamon pr., Oxford, U.K., 245-253.

READ, K. R. H., 1963. Thermal inactivation of preparations of aspartic/glutamic transaminase from species of bivalved molluscs from the sublitteral and intertidal zones. Comp. Biochem. Physiol. 9, 161-180.

- 1964. Comparative biochemistry of adaptations of poikilotherms to the thermal environment. In: Experimental marine ecology. Proceedings of a symposium ... Graduate School of Oceanography, Kingston, R.I. (Occ. Publs Narrangansett mar. Lab. 2, 39-47).

Syinkr, V. B., 1959. Spermatozoon thermostability in Rana temporaria L. and Rana ridibunda PaLl. Tsitologiya 1, 580-585.

Usmakov, B. P., 1963a. Cytophysiological analysis of intraspecies divergence of Rana ridibunda PALl. In: Problems of cytoecology of animals. USSR Acad. Sci., Moscow, 145-157 (Summary in English). 
- 1963b. Changes of cellular heat resistance in ontogenesis and problem of conservatism of cells of higher poikilothermal animals. In: Problems of cytoecology of animals. USSR Acad. Sci., Moscow, 21-42 (Summary in English).

- 1964a. Thermostability of cells and proteins of poikilotherms and its significance in speciation. Pbysiol. Rev. 44, 518-560.

- 1964b. Thermostability of cells and protoplasmic proteins in poikilotherms as related to the problem of species. In: The cell and environmental temperature. Ed. by A. S. Troshin. USSR Acad. Sci., Moscow; Pergamon pr., Oxford, U.K., 214-222.

- 1965. The present-day state of the problem of heat injury mechanism and causes of changes in cell thermostability. In: Heat resistance of cells of animals. Moscow, 5-54.

- \& Kusakina, A. A., 1960. On lability and conservatism of the animal cell adaptation as discovered on the protein level. Tsitologiya 2, 428-441.

- Vinogradova, A. N. 8 Kusakina, A. A., 1962. Cytophysiological analysis of intraspecies differentiation of Coregonus autumnalis and Thymalus arcticus of the Baikal Lake. $Z \mathrm{~h}$. obshch. Biol. 23, 56-63 (Summary in English).

VEGOTSKY, A. \& Fox, S. W., 1962. Protein molecules: intraspecific and interspecific variations. In: Comparative biochemistry. Ed. by M. Florkin \& H. S. Mason. Acad. pr., New York, Vol. $4 \mathrm{~B}, 185-244$.

VINOGRADOVA, A. N., 1961. The thermostability of succinicdehydrogenase of Rana temporaria and Rana ridibunda muscles and the changes in the enzyme activity during acclimatization. T'sitologiya 3, 595-598.

- 1963a. Heat resistance and optimal temperature of adenosinetriphosphatase activity of actomyosin in Carcinus maenas (L.), Hyas araneus boeki BrR., Raja clavata L. and Raja radiata Donov. from the Black and the Barents seas. In: Problems of cytoecology of animals. USSR Acad. Sci., Moscow, 189-194 (Summary in English).

- 1963b. Investigation of heat resistance of actomyosin of T'estudo horsfieldi Gray and Emys orbicularis (L.) in connection with the problem of adaptation to living in deserts. In: Problems of cyroecology of animals. USSR Acad. Sci., Moscow, 195-198 (Summary in English).

- 1963c. Thermostability and temperature optimum of ATP ase activity of actomyosin of two species of marine mollusca. Tsitologiya 5, 246-249.

- 1965. The thermostability of actomyosin and myosin in two species of frogs. In: Heat resistance of cells of animals. Moscow, 188-192.

- \& Kusakina, A. A., 1963. Heat resistance of protoplasmic proteins in representatives of different populations of Rana ridibunda PALl. In: Problems of cytoecology of animals. USSR Acad. Sci., Moscow, 158-162 (Summary in English).

Wilson, A. C., Kaplan, N. O., Levine, L., Pesce, A., Rerchirn, M. \& Allison, W. S., 1964. Evolution of lactic dehydrogenases. Fedn Proc. Fedn Am. Socs exp. Biol. 23 (Pt 6), $1258-1267$.

\section{Discussion (by correspondence) following the paper by UsHakov}

KINNE: In your interesting considerations concerning the biological significance of associated changes in protein thermostability during speciation, you have made two important suggestions: (1) These changes occur primarily in proteins limiting the thermostability (upper lethal temperature limits) of gametes and embryonic cells at early cleavage stages in relation to changes in reproductive temperature. (2) These changes are due to phylogenetic adaptations of organisms within the range of normal temperatures; the thermostability of enzymes would therefore be correlated to their rates of activity under normal temperature conditions. It seems to me that stress temperatures causing sublethal readjustments to altered intensity patterns of temperature (e. g. changes ultimately resulting in more suitable rates and efficiencies of metabolic processes or in an increase in the competitive potential of the organisms involved) may be of greater ecological, and hence phylogenetic, importance than temperature effects, which 
are (a) immediately lethal, causing death within minutes, hours or days, or (b) representing the normal range, and thus can hardly be expected to act as a very effective source for selective processes.

UsHakov: When discussing the question of the biological significance of correlated interspecific differences in the thermostability of proteins we confined ourselves to considering two different hypotheses, one of which associates this phenomenon with "capacity-adaptation", and the second, with "resistance-adaptation", according to PRECHr's terminology. It seems to me that "resistance-adaptation" includes the response of an organism to the effect of sublethal as well as lethal temperatures. That is why the important role of adaptation to sublethal temperature, about which we have spoken, appears to be of principal significance for a detailed analysis of the hypothesis connecting correlated changes in protein thermostability with the problem of "resistance-adaptation". I cannot but agree with you that adaptation to sublethal temperatures should be of primary evolutionary importance, but at present I hesitate to determine the range of temperatures, the adaptation to which is most significant for the problems discussed in my report. 